\title{
Local peoples' responses to co-management regime in protected areas: A case study from Satchari National Park, Bangladesh
}

\author{
Sharif Ahmed Mukul ${ }^{\text {** }}$, A.Z.M. Manzoor Rashid ${ }^{\mathrm{b}, \mathrm{c}}$, Shimona A. Quazi ${ }^{\mathrm{d}, \mathrm{e}}$, \\ Mohammed Belal Uddin ${ }^{\mathrm{c}, \mathrm{f}}$ and Jefferson Fox ${ }^{\mathrm{e}}$ \\ ${ }^{a}$ School of Agriculture and Food Sciences, Faculty of Science, The University of Queensland, \\ Brisbane, QLD 4072, Australia; ${ }^{b}$ School of Law, University of Western Sydney, Sydney, Australia; \\ ${ }^{c}$ Department of Forestry and Environmental Science, School of Agriculture and Mineral Sciences, \\ Shahjalal University of Science and Technology, Sylhet 3114, Bangladesh; ${ }^{d}$ Department of Botany, \\ University of Hawai'i, 3190 Maile Way, Honolulu, Hawaii 96822, USA; ${ }^{e}$ East-West Center, 1601 \\ East-West Road, Honolulu, Hawaii 96848-1601, USA; ${ }^{f}$ Department of Biogeography, University of \\ Bayreuth, D-95440 Bayreuth, Germany
}

\begin{abstract}
Community-based natural resource management (CBNRM) is a rather recent and widely promoted, and hence, accepted paradigm for managing protected areas in most developing countries. Protected area managers in Bangladesh face challenges because of the complex sociocultural and political dynamics that result from the high population densities and extreme poverty of people living in or near lands designated for conservation. In recent years the government of Bangladesh, with active support from international aid and conservation agencies, has tried to develop a holistic approach to protected area management involving forest communities and user groups. This study seeks to explore the initial response to such intervention in a newly declared protected area in order to gain insights about wider implications in other parts of the country. The study was conducted between January 2006 and January 2007 in four villages located in or near Satchari National Park. Results suggest considerable change took place in household forest resource collection patterns, and people's dependency on non-forest income increased significantly during the project implementation period. The study also indicated that although changes occurred slowly, they brought improvements to the livelihoods of those relying on local forests.
\end{abstract}

Keywords: conflicts; forest-based livelihoods; alternative income generation; governance; Bangladesh

\section{Introduction}

Regardless of their enormous environmental and economic values, the, global loss and degradation of forests and biodiversity have accelerated at an alarming pace in recent years (Kaimowitz and Angelsen 1998). Over 15 million ha of natural forests are disappearing in the tropics every year; that is more than the area of Nepal, or of Arkansas in the United States (FAO 2006). These rapidly eroding forests have a profound and devastating global impact since tropical forests comprise the richest ecosystem on earth (Hirakuri 2003) It is also widely believed that the poorer populations of most developing countries, of whom a large proportion live in and around the remnants of the world's tropical forests, are somehow responsible for this deforestation and will be affected most by its consequences (Sunderlin et al. 2005).

*Corresponding author. Email: sharif_a_mukul@yahoo.com / s.mukul@uq.edu.au 
Establishment and management of protected areas (hereafter called "PAs") represent a key strategy in biodiversity conservation (Ormsby and Kaplin 2005). Such areas have long been thought to be the most effective and widespread measure for conserving nature and natural resources in situ and are considered to be the foundation of all national and regional conservation strategies (Mulongoy and Chape 2004). Over the last decades, many developing countries have markedly expanded the amount of their land under the PAs system in line with the international commitment to conserve biodiversity in situ (Mulongoy and Chape 2004). However, in many cases, the establishment of PAs has failed to achieve the desired outcomes, due to a pure ecological focus and a poor recognition of local and indigenous peoples' rights and practices (Nepal and Weber 1995; Ormsby and Kaplin 2005), leading to conflicts and mistrust between PA managers and local forest user communities (Borrini-Feyerbend 2002). Experiencing the consequences, local peoples' support and involvement for PA management have been viewed as important elements of enhanced conservation in recent years, especially in developing countries (Nagothu 2003; Wells and Mcshane 2004). Co-management of PAs represents one of these new strategies developed under the broad umbrella of community-based natural resource management (CBNRM). It enables local peoples to participate in PA management up to a certain extent and most often offers local communities some direct and indirect benefits related to park management (Brown 2003; Nagothu 2003). It has been promoted by various international conservation agencies (Fisher 2003; Jeanrenaud 2002) in many developing regions.

One of the most densely populated $\left(1,090\right.$ people $\left./ \mathrm{km}^{2}\right)$ countries in Asia, Bangladesh is an instructive microcosm of Asian conservation (World Bank 2009). The country was densely forested until the British colonial period, with about $20 \%$ forest cover, and even until 1980 it was home to about half the bird species and a quarter of all mammal species of South Asia (Poffenberger 2000). Even though the beginnings of the government's conservation efforts in the country can be traced back to 1966, before independence, very few of the goals were actually met, and today the actual forest cover is estimated at $6 \%$ of the country's total land mass; however, many species have already gone extinct locally (FAO 2006). At present, the country has 18 PAs (under The International Union for Conservation of Nature (IUCN) PA management categories IV and V) that cover approximately $1.67 \%$ of the total land area (Mukul et al. 2008). These figures are among the lowest in the world, despite the country's exceptionally rich biodiversity favored by unique geo-climatic conditions (Appanah and Ratnam 1992). At the same time, large numbers of the rural poor are either forest dwellers or forest dependent for their subsistence. Under such circumstances, "co-management" or "collaborative management" is indispensable to maintain Bangladesh's vanishing forests and biodiversity through sustaining local livelihoods (Mukul and Quazi 2009).

In spite of the country's long history of community involvement in forest management that started with taungya systems in 1871, and various social forestry projects since 1960s and onward (Poffenberger 2000), the concept of co-management or joint management in PAs is a new but very timely approach that could better promote the issues of sustainable development ensuring livelihoods and conservation. In 2002, the Forest Department (FD) developed a forest co-management program in PAs called the Nishorgo Support Project (hereafter called "the Project"), with active support from USAID (United States Agency for International Development). The Project ran until 2007. It was then relaunched and extended in 2009 based on earlier experience and lessons under the name "Integrated Protected Area Co-management" (IPAC), with broader scope and aims. During the Project period, the concept of co-management was implemented in five PAs. All the sites were located in the hilly areas of the northern, northeastern, and southern parts of the country; 
those areas harbor unique flora, fauna, several endangered primates, and were atypical compared to the otherwise flat, deltaic landscape of the country.

One of the key challenges, however, was to address mistrust and conflicts between local communities and the respective forest governing authorities that have so far hindered effective forest conservation in Bangladesh. A variety of initiatives were undertaken to address these issues and to increase people's active involvement in PA management and conservation. Apart from establishing a co-management committee with representatives from local elite, different forest user groups, local women, and so forth, the initiatives ranged from awareness-raising activities to support and development of alternative income generating options, such as nursery raising, fisheries, home gardening, livestock and poultry rearing, retraining of former illegal loggers by involving them in forest patrolling, and training local educated youth as eco-tour guides for emerging eco-tourism prospects.

As an initial step for assessing the progress of this new approach to conservation in Bangladesh, we collected both qualitative and quantitative data to explore the changing trends in forest uses, local livelihoods, and finally people's attitudes toward comanagement over a one-year period at one of the northeastern pilot sites. Our objective was to demonstrate the strength and weakness of this approach and provide "lessons learned" for use by others.

\section{Materials and methods}

\section{Study area}

Satchari National Park is one of the four PAs located in the northeastern hilly regions of Bangladesh. The national park was established in 2005 and covers 243 ha of the greater Raghunandan Hills Reserve (RF) within the Satchari Range (Figure 1). Administratively

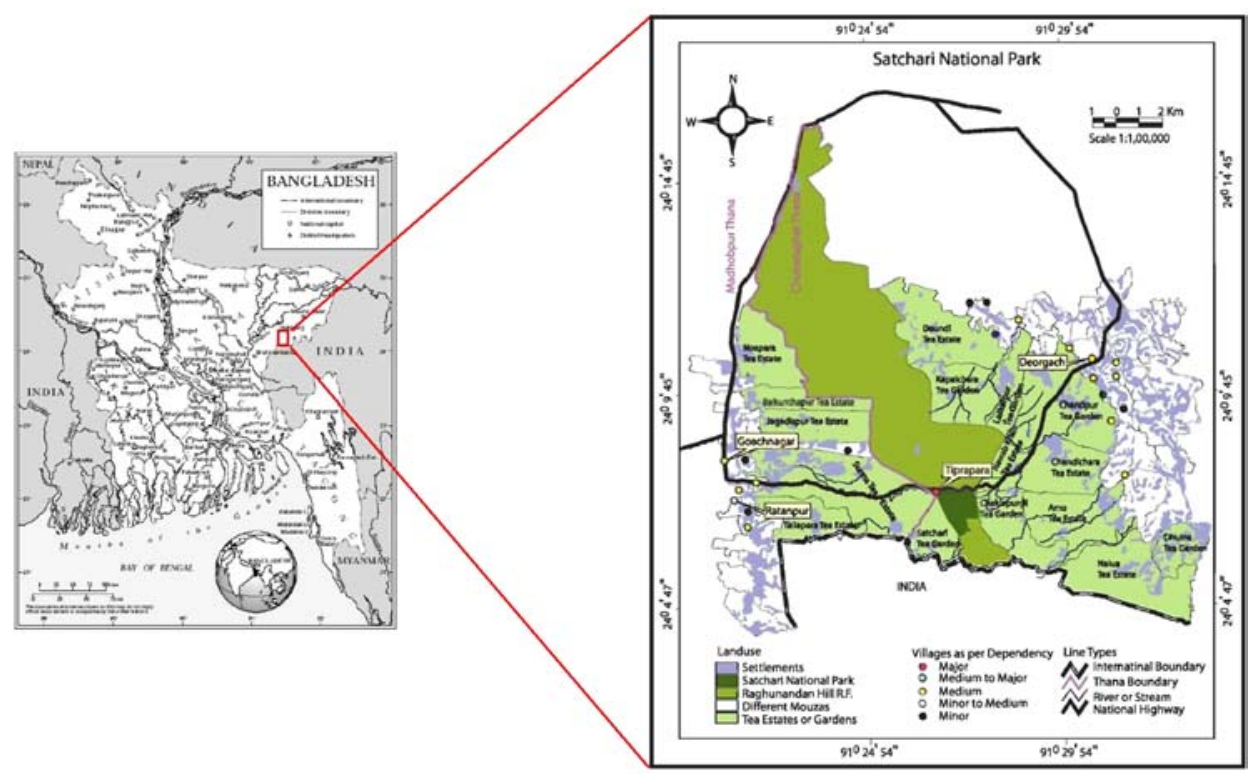

Figure 1. Location map of the study area. 
the park is located in Chunarughat Upazila (Upazila = subdistrict) of Habiganj District and is located about $130 \mathrm{~km}$ northeast of Dhaka, the capital city of Bangladesh.

Close to the Indian border, the park is mainly bordered by tea estates, rubber gardens, agar (Aquilaria agallocha Roxb.) plantations, and paddy fields. Forests in the park belong to the evergreen type, with 200 ha being "natural" forest and the rest being secondary vegetation and planted forest. The park is also one of the last habitats of an endangered, non-human primate: Hollock Gibbons (Hoolock hoolock) is the only ape species in South Asia and in the country (NSP 2006).

The topography of the park is undulating with slopes and hillocks, locally called tilla, ranging from 10 to $50 \mathrm{~m}$ in elevation. A number of small, sandy-bedded streams run across the forest, all of which dry out during the winter season. The average annual rainfall is $4,162 \mathrm{~mm}$. July is the wettest month, having an average of about $1,250 \mathrm{~mm}$ of rain, while December is the driest with no rainfall. May and October, the hottest months, have an average maximum temperature of approximately $32^{\circ} \mathrm{C}$, while January is the coldest month with the minimum temperature dropping to about $12^{\circ} \mathrm{C}$. The relative humidity of the area is about 74\% during December, while it is over 90\% July through August (Mollah et al. 2004).

\section{Selection of villages}

In Satchari, local people traditionally collected various resources from the national park and adjacent reserve forest. Mollah et al. (2004) identified a total of 19 villages having diverse degrees of interest and dependency on the park. Only one village is located within the national park and it is inhabited by an ethnic community called Tripura. The other villages that have stakes in the national park are located about $3-8 \mathrm{~km}$ away from the park. For this study, we randomly selected four villages, namely Tiprapara, Deorgach, Ratanpur, and Goachnagar, from each of the first four forest dependency categories (i.e., major; medium to major; medium and minor to medium) as identified by Mollah et al., including the only village inside the park-Tiprapara. However, after initial field observation, we made a change in the dependency level between Deorgach and Ratanpur (Table 1). Any village with only minor dependency on the park was not considered for the study.

\section{Data collection and field techniques}

The study was conducted within a time span of one year, from January 2006 to January 2007. Data and information were obtained through a series of field visits. We arranged

Table 1. Synthetic information on the study villages and the sampling.

\begin{tabular}{|c|c|c|c|c|}
\hline Village & $\begin{array}{l}\text { Location and } \\
\text { distance from } \\
\text { the park }\end{array}$ & $\begin{array}{l}\text { Population } \\
\text { size (HHs) }\end{array}$ & $\begin{array}{l}\text { Sample } \\
\text { size }(n)\end{array}$ & Forest practices* \\
\hline Tiprapara & Inside $(0 \mathrm{~km})$ & 22 & $\mathrm{n}=22$ & $\begin{array}{l}\text { Collect fuelwood, house building } \\
\text { materials, fruits and other NTFPs, } \\
\text { cultivate lemon and others }\end{array}$ \\
\hline Ratanpur & Outside $(2 \mathrm{~km})$ & 156 & $\mathrm{n}=16$ & $\begin{array}{l}\text { Mainly involved with illegal tree } \\
\text { felling and collecting fuelwood }\end{array}$ \\
\hline Deorgach & Outside east $(3 \mathrm{~km})$ & 316 & $\mathrm{n}=31$ & $\begin{array}{l}\text { Mainly collect fuelwood, some } \\
\text { involved with illegal tree felling }\end{array}$ \\
\hline Goachnagar & Outside west $(4 \mathrm{~km})$ & 328 & $\mathrm{n}=32$ & As above \\
\hline
\end{tabular}

Note: *As described by Mollah et al. (2004).

NTFPs $=$ non-timber forest products. 
some participatory rural appraisal (PRA) and focus group discussion exercises in each of the study villages to construct community maps and community profiles of the respective villages. Information gathered during the community mapping exercises was checked and verified through some random field visits in the villages with the help of a key informant for each of the villages.

Household surveys were conducted twice, during early 2006 and early 2007, in all the four villages. In Tiprapara, we took a 100\% sample (i.e., 22 respondents), since villagers were highly dependent on the park for their subsistence and income. In the other study locations, the sampling intensity was $10 \%$, with representation of each of the forest dependency categories (i.e., high, moderate, and low) by using a stratified random sampling approach.

Several methods have been developed, used, and described so far by a number of authors for assessing household income and forest dependency (see IIED 2003; Vedeld et al. 2004; Wollenberg and Nawir 1998, for examples). We used the focus group discussions to distribute households into three wealth and three forest dependency categories. For estimating household's net income from the forests, the following formula was used as prescribed by Ambrose-Oji (2003):

Net Forest Income: Direct cash benefits from selling of all harvested forest products (revenue) + market value of the consumed forest products which they may have otherwise purchased from the market (savings) - investment cost/opportunity cost.

For data collection and interviews we used a semi-structured questionnaire where we collected the details about household income, income from forests, products (for consumption and sale) collected from nearby forests, quantity or amount harvested, households' view and benefits from the existing PA management system, and expectations from this regime. Relevant data on household demography, literacy rate, and other livelihood related issues were also noted. It was critical to get information regarding households' illegal forest activities. We thus developed a friendly relationship with the respondents with the help of a key informant, and we guaranteed that data would be used anonymously. Both men and women were interviewed in the only ethnic village, Tiprapara (on the basis of availability), whereas only men were interviewed in the other villages. On each and every topic of the questionnaire, the respondent was free to express his or her views.

\section{Results}

\section{General overview of the respondents}

Information gathered during the focus group discussions was used to fix the wealth limits of three household categories-viz. extremely poor (monthly income below Tk 2,000 ${ }^{1}$ ), medium to poor (monthly income between Tk. 2,000 and Tk. 7,500), and rich (monthly income Tk. 7,500 or higher). Based on this scale, approximately $37 \%$ of the households were extremely poor, $32 \%$ were medium to poor $(32 \%)$, and $31 \%$ were rich. The overall literacy rate across the villages was about $54 \%$.

The primary occupations observed in the study villages were agriculture (mainly paddy cultivation: 37\%), followed by extraction of non-timber forest products (NTFPs: $18 \%$ ), illegal logging (18\%), daily labor (15\%), small business (5\%), government and nongovernment services (4\%), and overseas employment (2\%). The scenario was, however, quite different in Tiprapara, since it is located inside the park and there were no agricultural fields, unlike the other villages. Villagers from Tiprapara were found to work mainly as daily laborers (38.5\%), followed by NTFPs extractors (mainly firewood: $32 \%$ ). 
Forest patrolling was one of the main services done by Tiprapara males (82\%) after the Project activities began.

\section{Co-management activities: A means of livelihoods and community participation}

The Nishorgo Program of the Forest Department developed a range of options and incentives for the people of the Satchari area. These were aimed mainly at regulating conventional forest use by the people living inside the forests and in adjoining villages. However, there were some differences in strategies taken for interior and exterior villages. The village located inside the park was particularly vulnerable to the changes that occurred when the park was declared, but at the same time exterior villages could be impacted in ways that were less visible or obvious, yet equally important for long-term management.

The ethnic Tripura community living inside the park holds a long tradition of various forest practices, like jhum or shifting cultivation, hunting of wild animals, collection of firewood, fruit and house building/construction materials from the adjoining forest. Since the declaration of the area as a PA reduced access to many of these uses, the Forest Department granted formal permission to the Tripura community to cultivate lemon-one of their traditional income sources-within a designated zone within the park. Additionally, since there were no alternate energy sources available for domestic use, the villagers got informal permission to collect firewood for their own consumption in an ecologically feasible way (i.e., collection of only dead woods) from the adjoining reserve and national park area. Each Tripura household was also allotted 0.5 ha of denuded forestland from the park buffer area as part of a long-term benefit sharing agreement (J Roy, personal communication 2006).

The majority of the Tripura villagers started working as members of the Forest Department patrolling teams. Several teams of male adults from Tiprapara worked on rotations guarding the forest. Two educated youths from the Tripura community were also trained and promoted as eco-tour guides. The women were supported for fattening cattle, rearing pigs, and the traditional weaving of Tripura cloth. Both men and women received training and initial support for these ventures, and they eventually started contributing to their family earnings, though the level of contribution varied with the type of support. For example, earnings as an eco-tour guide and from Tripura weaving started immediately, though these were dependent solely on tourist seasons and number of tourists in the area, while women started getting benefits from livestock rearing after at least a year.

In the other three villages, incentives were confined mainly to technical support and financial assistance. To help decrease illegal logging, the project provided training and loans for alternative income generation activities such as nursery raising, home gardening, aquaculture, cattle rearing, and eco-tour guide training. Five groups of women were also assisted in raising funds on a cooperative basis, with an aim to further invest these funds in small enterprise development, purchasing cattle, and so forth. Table 2 lists the Project supported activities observed in the study villages during the survey period.

One of the problems in implementing these initiatives as identified during the focus group discussions was the uneven distribution of support within the villages. Those villagers who did not receive livelihood training or support from the co-management authorities expressed their dissatisfaction, since the creation of the PA had restricted their forest use and affected their incomes.

In Satchari, the Project also formed a co-management committee (CMC), made up of 19 members representing various forest stakeholder groups ranging from local elites, head of the ethnic Tripura community, and representatives of the locals who have long sustained their livelihoods from the forest. The objective of the committee was to allow 
Table 2. Alternative income-generating activities observed in the study villages.

\begin{tabular}{lcccc}
\hline Type of support & Tiprapara & Ratanpur & Deorgach & Goachnagar \\
\hline Cattle rearing/fattening & + & + & + & + \\
Eco-guide training & + & - & + & - \\
Fisheries & - & + & + & - \\
Forest patrolling team & + & + & - & - \\
Land (i.e., buffer area) & + & - & - & - \\
Lemon cultivation within the park & + & - & - & - \\
Nursery raising & - & + & + & - \\
Pig farming & + & - & - & - \\
Promotion of hand crafts & + & - & - & - \\
Vegetable farming & - & + & + & + \\
\hline
\end{tabular}

Source: Field survey (2006-2007); Key: $+=$ presence; $-=$ absence.

local people to actively contribute to the management decisions of the park by sharing and expressing their views and interests at regular committee meetings. Our focus group discussions indicated that in most cases, villagers felt that they had enough access to the $\mathrm{CMC}$, and they found themselves in a much stronger position after the Project than before, since they were consulted when making new decisions regarding the park management.

\section{Changing trends in forest use, forest dependency and forest-based income}

During the study period we found that many households, particularly poor households in the study villages, relied partly or entirely on the national park and surrounding reserve forest for firewood, timber, bamboo, fruit, medicinal plants, and other NTFPs. Daily laborers from all the study villages collected firewood during agricultural off periods and off days to supplement family income.

Quantitative analysis shows a changing trend in the collection of forest products, changes in local forest dependency levels, and changes in respondents' income sources. Three main forest products were considered: timber, firewood, and other NTFPs. Since findings for most NTFPs varied across the four sample villages, they were not considered individually in this analysis. Firewood was considered as a separate forest product due to its immense significance to local livelihoods. The findings suggested that people's involvement in forest product collection decreased over the study period. We also noticed a shift in people's dependency away from the forest, especially in Tiprapara and Ratanpur. The share of forest resources as an income source in total households' incomes also noticeably decreased. The findings are described in more details here.

\section{Forest use and forest products}

All the households of Tiprapara collected firewood from the forest for their own consumption and sometimes for sale, but only $60 \%$ of respondents from Ratanpur, $55 \%$ of those from Deorgach, and 56\% in Goachnagar reported collecting firewood from the park for sale or for their own use in 2006. In contrast, only a small number of households, from outside the park, harvested timber in the park, and this was always for sale. Table 3 shows the numbers of respondents from the study villages collecting forest products from SNP for sale in 2006 and 2007.

Forest products extracted solely for commercial purposes decreased notably during the two reference periods. Around $18 \%$ of the respondents were involved in illegal logging in 


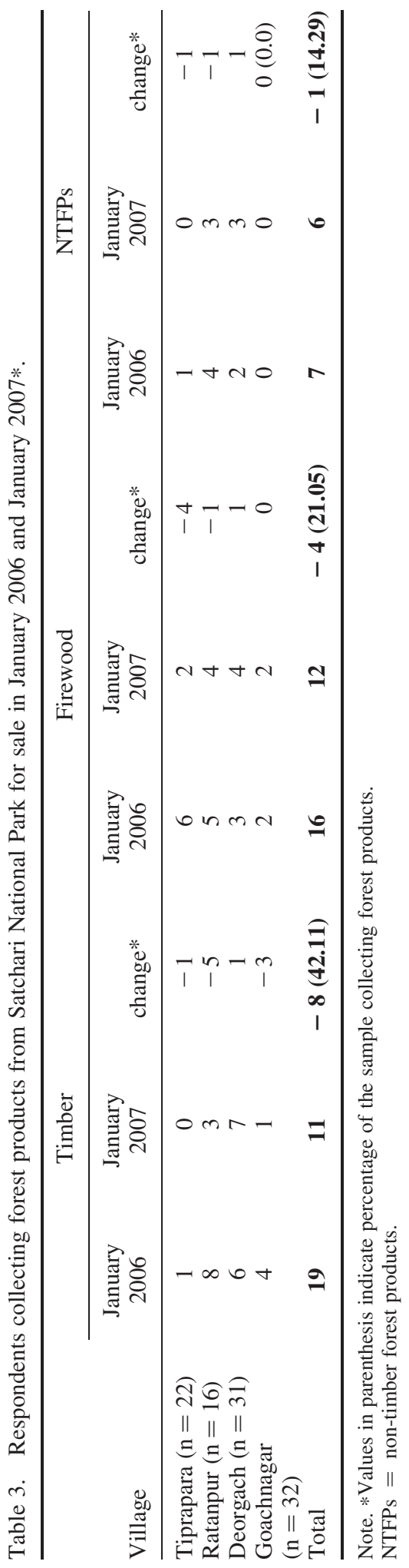


early 2006 , from nearby forests, which decreased to around $11 \%$ in early 2007 . Overall, households' involvement from across the villages in collecting firewood and other NTFPs for sale was also considerably reduced (Figure 2). The relative reduction in forest resource extraction was greater for the two villages with highest forest dependency, that is, Ratanpur and Tiprapara (Table 3). Both villages reported lower levels of resource extraction in 2007.

\section{Forest dependency}

Based on the contribution of forest products to households' annual gross income, three household forest dependency categories were determined in the focus group discussionsviz. low dependency ( $<$ Tk. 24,000 per year), moderate dependency (between 24,000 and 54,000 per year), and high dependency ( $>54,000$ per year). The study confirmed that, overall, people's dependency on forest products varied with their socio-economic condition-higher in the poor category than in the rich category (Figure 3).

Table 4 illustrates the changes in households' forest dependency between 2006 and 2007. The changes were most prominent in the most forest-dependent village, Tiprapara, which is also the only village inside the park. The percentage of people in the most dependent group dropped from $67 \%$ (15 persons) to $18 \%$ (4 persons), mostly moving into the moderately dependent class. The same trend was observed in Ratanpur, although with a much lower magnitude. The less forest-dependent villages, Deorgach and Goachnagar, showed negligible changes. The reason for this pattern was primarily because the park interventions and efforts to change household dependency on forest resources were concentrated mostly in those villages with the highest dependency levels.

\section{Forest-based incomes and local livelihoods}

We found an overall shift away from forest resources in local peoples' income patterns over the study period for all four villages. We classified local peoples' incomes into two main categories: forest-based income and non-forest income. Forest-based income was further divided into three sections, namely, income from timber, income from firewood, and income from NTFPs. All other forms of income were considered and calculated as non-forest income, including income from business, agriculture, services, and income-

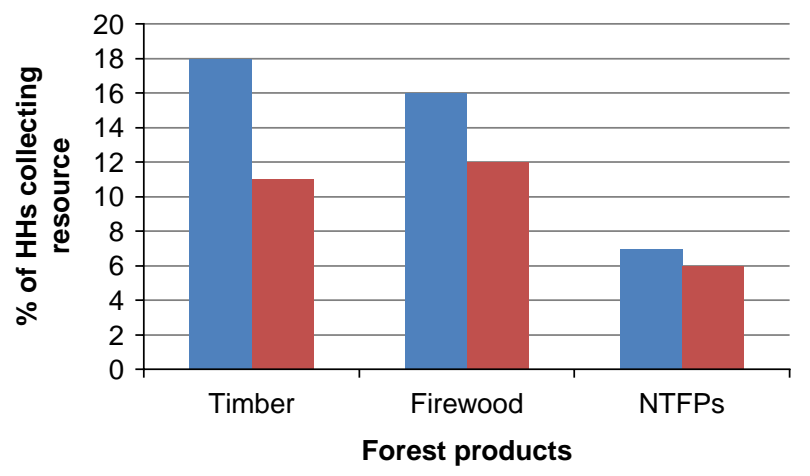

- January $2006 \quad$ January 2007

Figure 2. Change in collection of forest products. 


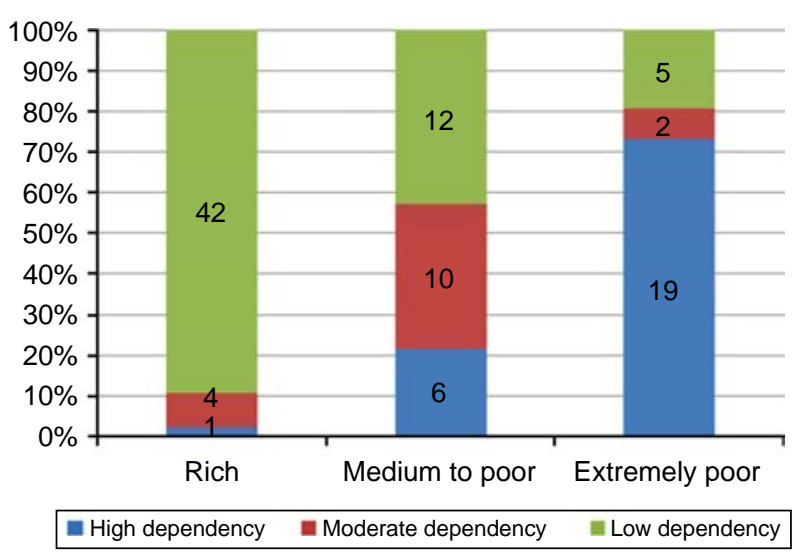

Figure 3. Variation of forest dependency according to income level.

Table 4. Households' distribution by forest dependency categories in study villages in January 2006 and January 2007 (in percentages).

\begin{tabular}{lcccccr}
\hline & \multicolumn{2}{c}{ High Dependency } & \multicolumn{2}{c}{ Moderate Dependency } & \multicolumn{2}{c}{ Low Dependency } \\
\cline { 2 - 7 } Village & 2006 & 2007 & 2006 & 2007 & 2006 & 2007 \\
\hline Tiprapara & 67 & 18 & 17 & 59 & 16 & 23 \\
Ratanpur & 22 & 16 & 29 & 31 & 49 & 53 \\
Deorgach & 11 & 12 & 12 & 9 & 77 & 79 \\
Goachnagar & 8 & 9 & 13 & 11 & 79 & 80 \\
\hline
\end{tabular}

generating activities facilitated by the park. Figure 4 illustrates the overall change across the four villages in various income sources between January 2006 and January 2007. Nonforest income over all our four study villages increased from $68 \%$ to $77 \%$. The reason for this shift can be attributed to increased opportunities for people to work in non-forest sectors, including alternative income-generating activities under the co-management project. For example, a number of illegal loggers had stopped this activity and moved to other occupations, like nursery raising and forest patrolling.

\section{Attitudinal changes and responses toward co-management}

Although access to the support schemes for people in the Satchari area was inadequate, the initial results of these efforts, appreciated through the focus group discussions, were encouraging.

During the study period, we met several former illegal loggers who were later involved in various environmental restoration activities with park support. For these people, comanagement offered a chance to improve their social status and later to find other ways to contribute to forest protection in spite of their past role. A former illegal logger reported the following in early 2007: "We were illegal loggers, but the Nishorgo Support Project recruited us as forest protectors, which has made our lives more secure. We are more respectable in society than ever" (S. Tripura, personal communication 2007). 


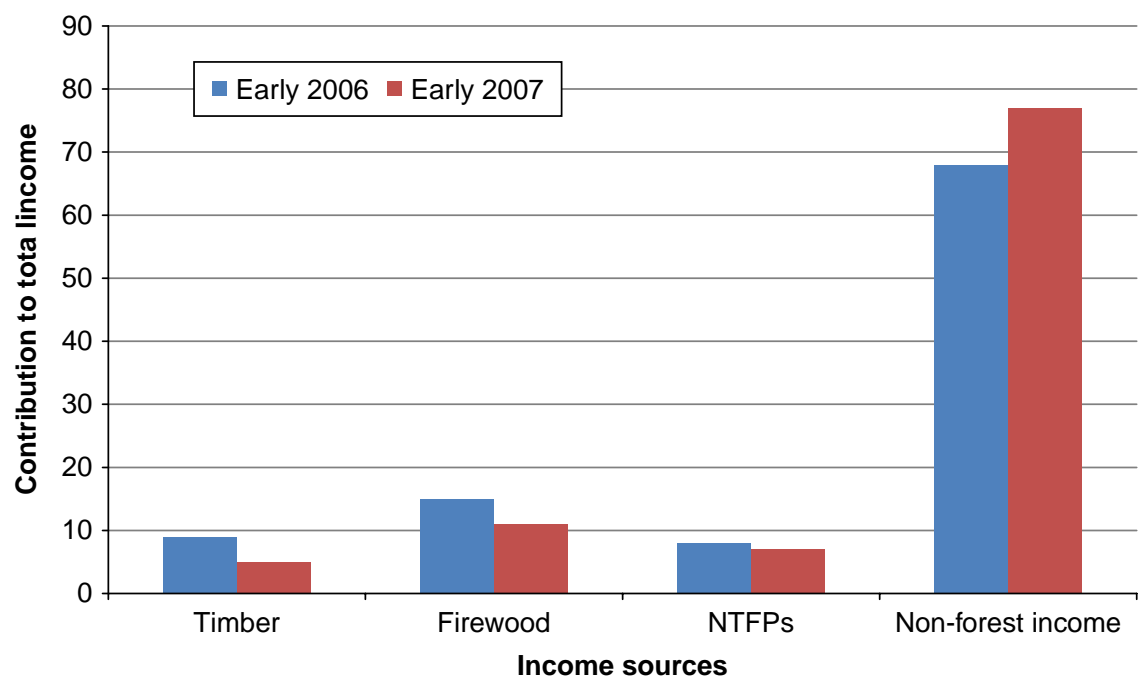

Figure 4. Shift in income source during the survey period.

\section{Discussion and conclusion}

The initial objective of the Nishorgo Support Project was, through the development of a community-based PA management system, to provide and create alternatives to deforestation for forest-dependent people. Ensuring livelihood security for local stakeholders is critical in forest conservation; hence, the creation of alternative income sources to shift stakeholders' dependency away from the forests was a specific objective of the Nishorgo Project.

Though this scheme was only recently introduced to Satchari National Park, we believe our study fairly accurately represents the overall situation in response to this new paradigm. We found small but definite positive changes in PA management, local people's attitudes and responses to co-management, and forest resource collection patterns, even within the short period of our assessment. People's income sources and dependency on protected forests have noticeably shifted away from forest areas. On the whole, satisfaction and morale were high and there were some exemplary success stories. The system introduced by the Nishorgo Project could foster a sense of community empowerment through ensuring community participation in decision making and benefit sharing.

However, we also uncovered some inequities in the distribution of co-management schemes and benefits that may become problematic if left unattended. The uneven distribution of alternative income generating support, both within and across the villages, was voiced as a problem by villagers. Benefits were not always equitably or rationally distributed within the same village and rural producers voiced concern for improved market access to sell their products. Such issues can undermine conservation efforts by wasting limited resources and reducing people's confidence in a project. Similar observations and comments were made by Bajracharya et al. (2006), Mehta and Heinen (2001), Nagothu (2003), and Silori (2007) from the Annapurna and Makalu-Barun conservation areas of Nepal, the Sariska Tiger Reserve, and the Nanda Devi Biosphere Reserve of India, respectively, where they found that limited income generation opportunities in the villages outside these PAs negatively correlated with effective conservation in these protected areas. It was also observed that some people were only 
interested in getting financial support in the form of cash from the respective authority despite their lack of involvement in any kind of motivational or other development activities. In some instances, despite limited intervention by the Project, the condition of poor people relying on the forest became worse than it was before. This discouraging result was also noted by Malla (2000) from his study in Nepal. Baral et al. (2007) also urged for behavioral changes of the target population that may take a decade to reach the desired outcome. It seems clear that people who get more benefits from co-management interventions are likely to contribute more to conservation, and successful PA management systems depend largely on the effective involvement of local communities in park management (Mbile et al. 2005; Nagothu 2003).

Another critical long-term issue for park management in Bangladesh is the need for good governance. This is vital to ensure sustainable development for biodiversity conservation in general and PAs in particular. Ensuring good governance at the national and local levels to attain desired goals from co-management intervention requires more attention to local demands. Unfortunately, in Bangladesh, there exists a historically long and widespread pattern of corruption and abuse at various levels of forest management, and this has been one of the main barriers in establishing co-management at all five pilot sites. However, co-management is an opportunity for the Forest Department and local stakeholders to open channels of communication that were previously non-existent. Our study highlighted the fact that progress is being made in this area, yet both local people in PAs and local authorities are still unclear as to their rights and responsibilities with respect to park management. To address these gaps, the project needs to ensure that local stakeholders are empowered, good practices for building a holistic and effective PA management system are implemented, and a secure legal framework for protecting stakeholders' rights is realized (Craig 2002).

Undoubtedly, intense land use disputes with local people are one of the major factors hindering PA management in developing countries (Nepal and Weber 1995); maintaining harmony between sustainable development and biodiversity conservation is a challenging task, especially in countries like Bangladesh with high population pressure, land use conflicts, economic constraints, and environmental threats (Redford et al. 2008). On the other side, these disputes or conflicts could also be a starting point to work with comanagement (Castro and Nielsen 2001). While many researchers have warned against seeing co-management as a universal remedy for legitimacy (Brown 2003), conflicts between local people and PA managers may also enhance the development of policies that address both conservation and the economic goals necessary for local development (Colfer 2005; Nepal and Weber 1995). Because people in developing countries are dependent on PAs for their livelihood needs and because they are the most vulnerable party in the establishment of PAs, there needs to be more flexibility in the system. This may be accomplished by fixing an allowable resource extraction limit that offers both ecological and economical sustainability in local environments and livelihoods. Long-term sustainability of co-management in Satchari National Park, as in most protected areas in the developing world, ultimately depends on poverty reduction through broad, equitable, and appropriate distribution of alternative income-generating programmes to local people.

\section{Acknowledgements}

The research was partially funded by USAID under a joint fellowship programme of East-West Center and Nishorgo Support Project. We appreciated the all-out support of Mr. Joydip Roy during 
our field visits. The field assistance of Tito, Nobel, and Pranto also is gratefully acknowledged. Thanks also to Ms. Elizabeth Thompson for her effort in improving the language of an earlier version of this manuscript. We express our deep gratitude to the inhabitants of our four study villages for their heartiest cooperation and information sharing. The valuable comments and suggestions made by two anonymous reviewers and editor of the journal were very useful to improve the quality of the manuscript.

\section{Note}

1 Bangladeshi currency: 69 Taka, Tk $=1$ U.S.\$ (at time of study).

\section{References}

Ambrose-Oji B. 2003. The contribution of NTFPs to the livelihoods of the "forest poor": Evidence from the tropical forest zone of south-west Cameroon. Int For Rev. 5(2):106-117.

Appanah S, Ratnam L. 1992. The importance of forest biodiversity to developing countries in Asia. J Trop For Science. 5(2):201-215.

Bajracharya SB, Furley PA, Newton AC. 2006. Impacts of community-based conservation on local communities in the Annapurna conservation area. Nepal. Bio and Cons. 15:2765-2786.

Baral N, Stern MJ, Heinen JT. 2007. Integrated conservation and development project life cycles in the Annapurna conservation area, Nepal: Is development overpowering conservation? Bio Cons. 16:2903-2917.

Borrini-Feyerbend G. 2002. Indigenous and local communities and protected areas: Rethinking the relationship. Parks. 12(2):5-15.

Brown K. 2003. Three challenges for a real people-centred conservation. Glob Ecol Bio. 12:89-92.

Castro AP, Nielsen E. 2001. Indigenous people and co-management: Implications for conflict management. Envir Science Pol. 4:229-239.

Colfer CJP. 2005. The complex forest: Communities, uncertainty and adaptive collaborative management. Washington (DC): Resources For the Future (RFF) Press.

Craig D. 2002. Recognizing indigenous rights through co-management regimes: Canadian and Australian experiences. New Zealand J Env Law. 6:199-255.

Fisher RJ. 2003. Innovations, persistence and change: Reflections on the state of community forestry. In: The community forestry current innovations and experiences. Regional Community Forestry Training Center (RECOFTC) and FAO-Regional Office for Asia and the Pacific (FAORAP). Bangkok (Thailand). p. 16-29.

Food and Agriculture Organization of the United Nations (FAO). 2006. Global Forest Resource Assessment 2005: Progress towards sustainable forest management. FAO Forestry Paper 147. Rome (Italy): Author.

Hirakuri SR. 2003. Can law save the forest? Bogor (Indonesia): Center for International Forestry Research.

International Institute for Environment and Development (IIED). 2003. Valuing forests: A review of methods and applications in developing countries. London (England): Environmental Economics Programme.

Jeanrenaud S. 2002. People-Oriented approaches in global conservation: Is the leopard changing its spots? London (England): IIED; Brighton (UK): Institute for Development Studies.

Kaimowitz D, Angelsen A. 1998. Economic models of tropical deforestation: A review. Bogor (Indonesia): CIFOR.

Malla YB. 2000. Impact of community forestry on rural livelihoods and food security. Unasylva. 202(52):37-45.

Mbile P, Vabi M, Meboka M, Okon D, Arrey-Mbo J, Nkongho F, Ebong E. 2005. Linking management and livelihood in environmental conservation: Case of the Korup National Park Cameroon. J Envl Man. 76:1-13.

Mehta JN, Heinen JT. 2001. Does community based conservation shape favorable attitudes among locals? An empirical study from Nepal. Env Man. 28(2):165-177.

Mollah AR, Kundu DK, Rahman MM. 2004. Site-level field appraisal for protected area comanagement: Satchari Reserve Forest. Dhaka (Bangladesh): Nature Conservation Management (NACOM). 
Mukul SA, Quazi SA. 2009. Communities in conservation: Changing protected area management and enhanced conservation in Bangladesh. In: Leslie RN, editor. Proceedings of the international conference., "The Future of Forests in Asia and the Pacific: Outlook for 2020"; October 16-18, 2007; Chiang Mai, Thailand. p. 143-159.

Mukul SA, Uddin MB, Uddin MS, Khan MASA, Marzan B. 2008. Protected areas of Bangladesh: Current status and efficacy for biodiversity conservation. Proc. Pakistan Acad. Sci. 45(2):59-68.

Mulongoy KJ, Chape SP 2004. Protected areas and biodiversity: An overview of key issues. Montreal (Canada): Secretariat of the Convention on Biological Diversity (SCBD); Cambridge (UK): UNEP-WCMC.

Nagothu US. 2003. Local people's attitudes towards conservation and wildlife tourism around Sariska Tiger Reserve. India. J Env Man. 69:339-347.

Nepal SK, Weber KE. 1995. Managing resources and resolving conflicts: National parks and local people. Int J Sus Dev World Eco. 2:11-25.

Nishorgo Support Project (NSP). 2006. Protected areas of Bangladesh: A visitor's guide. Dhaka (Bangladesh): NSP.

Ormsby A, Kaplin BA. 2005. A framework for understanding community resident perceptions of Masoala National Park. Madagascar. Env Con. 32(2):156-164.

Poffenberger M, editor. 2000. Communities and forest management in South Asia. Bohol (Philippines): IUCN, DFID, and Asia Forest Network. p. 35-46.

Redford KH, Levy MA, Sanderson EW, de Sherbinin A. 2008. What is the role for conservation organization in poverty in the world's wild places? Oryx. 42(4):516-528.

Silori CS. 2007. Perception of local people towards conservation of forest resources in Nanda Devi Biosphere Reserve, north-western Himalaya, India. Bio Con. 16:211-222.

Sunderlin WD, Angelsen A, Belcher B, Burgers P, Nasi R, Santoso L, Wunder S. 2005. Livelihoods, forests, and conservation in developing countries: An overview. World Dev. 33(9):1383-1402.

Vedeld P, Angelsen A, Sjaastad E, Berg GK. 2004. Counting on the environment: Forest incomes and the rural poor. Environmental Economics Series Paper No. 98. Washington (DC): The World Bank Environment Department.

Wells MP, Mcshane TO. 2004. Integrating protected area management with local needs and aspirations. Ambio. 33(8):513-519.

Wollenberg E, Nawir AS. 1998. Estimating the incomes of peoples who depend on forests. In: Wollenberg E, Ingles A, editors. Incomes from the forests-methods for the development and conservation of forest products for local communities. Bogor (Indonesia): CIFOR; Bangkok (Thailand): IUCN. p. 157-187.

World Bank. (2009). World Bank Development Indicators Database [Internet]. Available from: http://web.worldbank.org/. Accessed 14 November 2009. 